\title{
The Cleridae of Lord Howe Island, with Descriptions of Two New Species (Coleoptera: Cleroidea)
}

\author{
JUSTIN S. BARTLETT \\ Entomology Collection, Queensland Primary Industries and Fisheries, \\ 80 Meiers Road, Indooroopilly Queensland 4068, Australia \\ justin.bartlett@dpi.qld.gov.au
}

\begin{abstract}
Thriocerodes decussates n.sp. and Tarsostenodes howensis n.sp. are described from Lord Howe Island off eastern Australia. A key to all species known from the island is provided and brief summary information for three previously described species is given. The clerid fauna of Lord Howe Island consists of three endemic species, one of which is presumed extinct, and two species introduced from eastern Australia.
\end{abstract}

BARTLETT, Justin S., 2009. The Cleridae of Lord Howe Island, with descriptions of two new species (Coleoptera: Cleroidea). Records of the Australian Museum 61(3): 225-228.

The beetle family Cleridae is comprised of approximately 4000 mostly predatory species assigned to just over 300 genera (based on Gerstmeier 2000). Lord Howe Island is an isolated oceanic island of volcanic origin located approximately 700 kilometers northeast of Sydney, Australia ( $\left.31^{\circ} 30^{\prime} \mathrm{S} 159^{\circ} 04^{\prime} \mathrm{E}\right)$ (Environment Australia 2002). At present only one clerid species, the flightless Cormodes darwini Pascoe, has been described from Lord Howe Island, though it has not been collected for almost 100 years and is now presumed extinct (DECC 2007).

Surveys of Lord Howe Island by Australian Museum staff during the years 2000 and 2001 have produced the most comprehensive sample of Cleridae from the island to date. Identified from this material are two Australian species, Lemidia subaenea Gorham and Thriocerodes bipartitus Pic, apparently introduced to the island by human activity, and two undescribed, presumably endemic, species belonging to the genera Thriocerodes Wolcott \& Dybas and Tarsostenodes Blackburn (the former genus, widely distributed throughout Australia, was hitherto represented by five species, the latter, known from Victoria, New South Wales and Queensland, by seven species). No specimens of $C$. darwini were among the recently collected material.
In this paper Thriocerodes decussates n.sp. and Tarsostenodes howensis n.sp. are described and illustrated, and a dichotomous key to all five species presented. Additionally, brief details are given for $C$. darwini, $L$. subaenea and $T$. bipartitus, including a list of repositories holding Lord Howe collected specimens for each taxon.

\section{Materials and methods}

Adult beetles were studied and measured using a Nikon SMZ1500 stereo dissecting microscope fitted with a scale reticule. Total length is the distance from the distal limit of the clypeus to the elytral apices. Elytral and pronotal length to width ratios were calculated from measurements made of the longest and broadest extremities of those body parts. Terminology used herein follows Lawrence and Britton (1994) and Ekis (1977). Antennomere is abbreviated to "A". Habitus images of adults were constructed, with the aid of Helicon Focus montage software, from photographs taken through a Nikon SMZ1500 stereo dissecting microscope fitted with a Prior Proscan II stepping-motor and a Nikon DS U2/DS-Fi1 digital image capture system. 


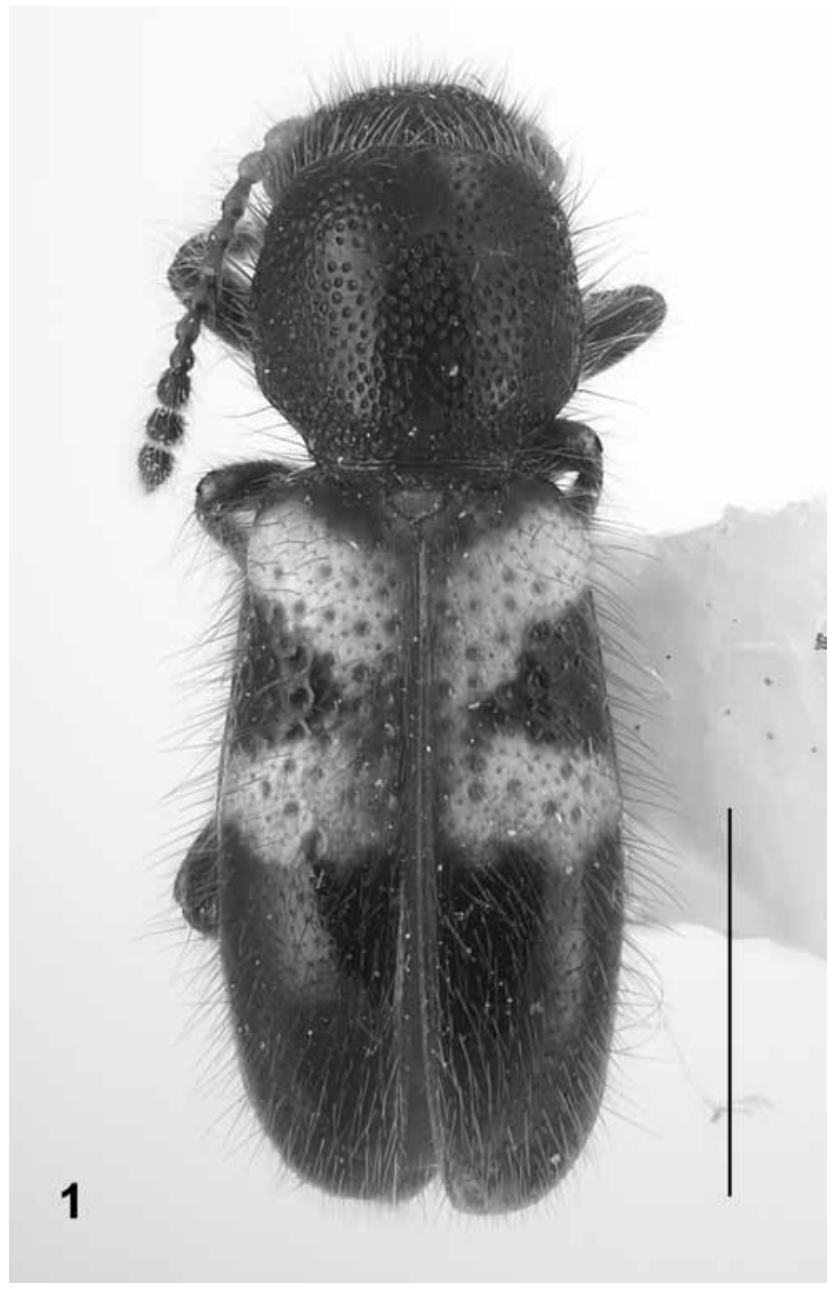

Figure 1. Thriocerodes decussates $\mathrm{n} . \mathrm{sp}$. holotype, scale $=1 \mathrm{~mm}$.

Specimen repositories are abbreviated as follows: AMS: Australian Museum, Sydney, Australia; ANIC: Australian National Insect Collection, Canberra, Australia; BMNH: Natural History Museum, London, United Kingdom; MNHN: Muséum national d'Histoire naturelle, Paris, France; MVMA: Museum Victoria, Melbourne, Australia; QM: Queensland Museum, South Brisbane, Australia; SAM: South Australian Museum, Adelaide, Australia.

\section{Cormodes darwini Pascoe (Clerinae)}

This conspicuous brachypterous species was described from, and is endemic to, Lord Howe Island, though it is now presumed extinct (likely due to predation by rats). Twentyfour specimens are known: AMS (5), SAM (9), BMNH (3), MNHN (3), MVMA (3) and QM (1). One AMS specimen was collected from Kentia palms (Howea sp.).

\section{Lemidia subaenea Gorham (Hydnocerinae)}

Described in 1877 from New South Wales and Tasmania, $L$. subaenea is likely to have been introduced to Lord Howe Island from southeastern Australia. Three Lord Howe collected specimens are known: AMS (2) and ANIC (1); the earliest being that collected by T.G. Campbell in 1956 (ANIC specimen). In Tasmania L. subaenea is predatory on the larvae of Synanthedon tipuliformis (Clerck) (Lepidoptera: Sesiidae) tunnelling in Ribes nigrum (Hardy 1982) while in southeastern Australia it is a predator of psyllids on Acacia (New 1978).

\section{Thriocerodes bipartitus (Pic) (Enopliinae)}

Likely introduced to Lord Howe Island, T. bipartitus is otherwise known from Queensland and the Northern Territory in Australia. Six Lord Howe collected specimens are known: AMS (3) and ANIC (3); first collected from Lord Howe Island in 1985 by G. Bornemissza (ANIC specimen).

\section{Thriocerodes decussates n.sp.}

Fig. 1

Type material. Lord Howe Island: HOLOTYPE: AMS K185981, 1/3 way up Goat House Trail (1st patch of palms) (31 $\left.33^{\circ} 47^{\prime \prime S} 159^{\circ} 05^{\prime} 09^{\prime \prime E}\right), 23$ Nov. 2001, C.Reid, beating palms etc, c.280 m. PARATYPE (1): AMS K185982, same data as holotype.

Diagnosis. Small, compact, flightless; dorsum densely vested with fine setae; pronotum strongly convex; body black-brown with yellow X-shaped maculation across basal half of elytra; unlikely to be confused with any other clerid on Lord Howe Island.

Description. Total length: $3.4-4.1 \mathrm{~mm}$. Head black-brown basally, frons medially and clypeus red-brown; frons, vertex and genae behind eyes distributed with a dense network of wrinkled punctation, densely vested with long pale posteriorly directed setae; eyes without distinct emargination; genae ventrally foveolate to smooth; gula smooth; labrum yellow-orange; maxillae and labium pale yellow; distal margins of terminal palpomeres slightly shorter than inner margins; antennae almost reaching pronotal base, vested with erect setae, pedicel and scape yellow, globular, A3-8 orange-brown, A3 elongate, A4-8 becoming progressively sub-globular, club dark brown, approximately as long as combined length of A5-8, A9-10 cupuliform, wider than long, their apical circumferences lined with a ring of short, white, forward directed setae, terminal segment obliquely rounded to vaguely trapezoidal. Prothorax black-brown, transverse (length:width $=0.9: 1$ ), sub-spherical; disc subglabrous though densely distributed with conspicuous circular foveolate punctation, densely vested with fine, pale, anteriorly positioned/posteriorly directed and posteriorly positioned/anteriorly directed setae, plus several longer erect setae. Elytra compact (length:width = 1.6:1), black-brown; basal half punctate, with a large yellowish $\mathrm{X}$-shaped maculation, apical half smooth; punctations without internal nodules, reduced to smooth circular subfoveolate impressions arranged in poorly-defined rows, those within black-brown area either side of X-shaped pattern more deeply impressed; disc densely vested with fine posteriorly directed setae plus several slightly thicker erect setae. Mesosternum dark brown, impressed with foveolate punctation. Metasternum dark brown laterally, orange brown medially, surface foveolate anteriorly, smooth posteriorly. 
Abdomen dark brown laterally, orange-brown medially; posterior margins of ventrites 2-4 transversely bordered by a pale orange band. Legs short, variously vested with short semi-decumbent, and long erect, setae; femora and tibiae dark brown, inner surface of femoral bases lightly infused with yellow; tarsi yellow.

Etymology. The specific epithet is descriptive of the distinctive pale X-shaped maculation of the elytra (Latin, decusso $=$ the Roman numeral $\mathrm{X}$ ).

Biology. The holotype and single paratype were beaten from palms.

Remarks. Although differing from typical Thriocerodes by its rounded pronotal disc and virtual absence of ocular emargination, no substantial characters were identified on which to base the exclusion of $T$. decussates n.sp. from the genus. Its assignment to Thriocerodes is based on the following shared characters: eyes widely separated, coarsely facetted; terminal palpomeres securiform; procoxal cavities open posteriorly; prothorax with complete lateral carina (which converges with the posterior margin of the hypomeron at the prothoracic hind angle); elytra compact, punctation not internally nodulate, epipleura converging near start of apical curve; legs short; tibial spur formula 1-2-1, pro- and meso-tarsi each with three pulvilli.

\section{Tarsostenodes howensis n.sp. (Tarsosteninae)}

\section{Fig. 2}

Type material. Lord Howe Island: HOLOTYPE: AMS K185983, 200

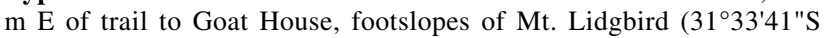
159 5'15"E), 24 Nov. 2000, ex Howea belmoreana, M. Elliot, N. Plunkett-Cole, LHIS029, beating. PARATYPES (16): 4 specimens, AMS K208418, AMS K208420, AMS K208421, AMS K208422, Valley of Shadows ( $\left.31^{\circ} 31^{\prime} 50 " \mathrm{~S} 159^{\circ} 4^{\prime} 36^{\prime \prime E}\right), 6$ Dec. 2000, R. Harris, LHI/RH/01, Active sampling; 2 specimens, AMS K185993, AMS K185989, jn [on?] Rocky Run \& Boat Harbour Trails (CBCR Site 24), c.30 m (31 ${ }^{\circ} 33^{\prime} 19 " \mathrm{~S}$ $159^{\circ} 05^{\prime} 33$ "E), 3 Dec. 2000, C. Reid, beating Pandanus/Howea/trees; 1 specimen, AMS K185992, path corner past Mutton Bird Pt. (31 ${ }^{\circ} 32^{\prime} \mathrm{S}$ $\left.159^{\circ} 05^{\prime} \mathrm{E}\right), 29$ Nov. 2000 , C. Reid, general beating veg.; 1 specimen, AMS K185991, 1/3 way up Goat House Trail (1st patch of palms) (31 $33^{\circ} 47^{\prime \prime S}$ $\left.159^{\circ} 05^{\prime} 09^{\prime \prime E}\right), 23$ Nov. 2001, C. Reid, beating palms etc, c. $280 \mathrm{~m} ; 1$ specimen, AMS K185990, saddle between Intermediate Hill and Goat House Cave ( $\left.31^{\circ} 32^{\prime} \mathrm{S} 159^{\circ} 05^{\prime} \mathrm{E}\right), 23$ Nov. 2001, C. Reid; 2 specimens, K185984 (now in QM; type reg. no. T156377), AMS K185985, Stephens Reserve, c. 10 m, (31 $\left.31^{\circ} 33^{\prime \prime S} 159^{\circ} 03^{\prime} 53 " E\right)$, beating, 29 Nov. 2000, C. Reid; 1 specimen, AMS K185988, same as last record but 09 Dec. 2000; 1 specimen, AMS K185987, same as last record but 04 Dec. 2000; 1 specimen, AMS K185994, beating bushes, Stevens Res., 11-14.v.2003, C. Reid; 1 specimen, K208419 (now in QM; type reg. no. T156378), Research

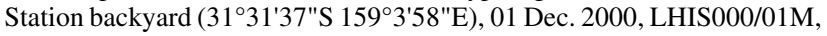
Passive sampling; 1 specimen, AMS K246847, R. Baxter, xii.1921, AMS K45627. All in Australian Museum, Sydney, unless otherwise indicated.

Diagnosis. Small, slender, volant species; body mostly yellowish with dark longitudinal markings (singular and medial on pronotum and head, paired and sub-sutural on elytra); elytra without callositous deposits; antennae long, reaching beyond base of pronotum; unlikely to be confused with any other clerid on Lord Howe Island.

Description. Total length: $3.8-5 \mathrm{~mm}$; body slender, predominantly yellow to pale orange, with brown longitudinal markings; setal vestiture pale, finely distributed. Head

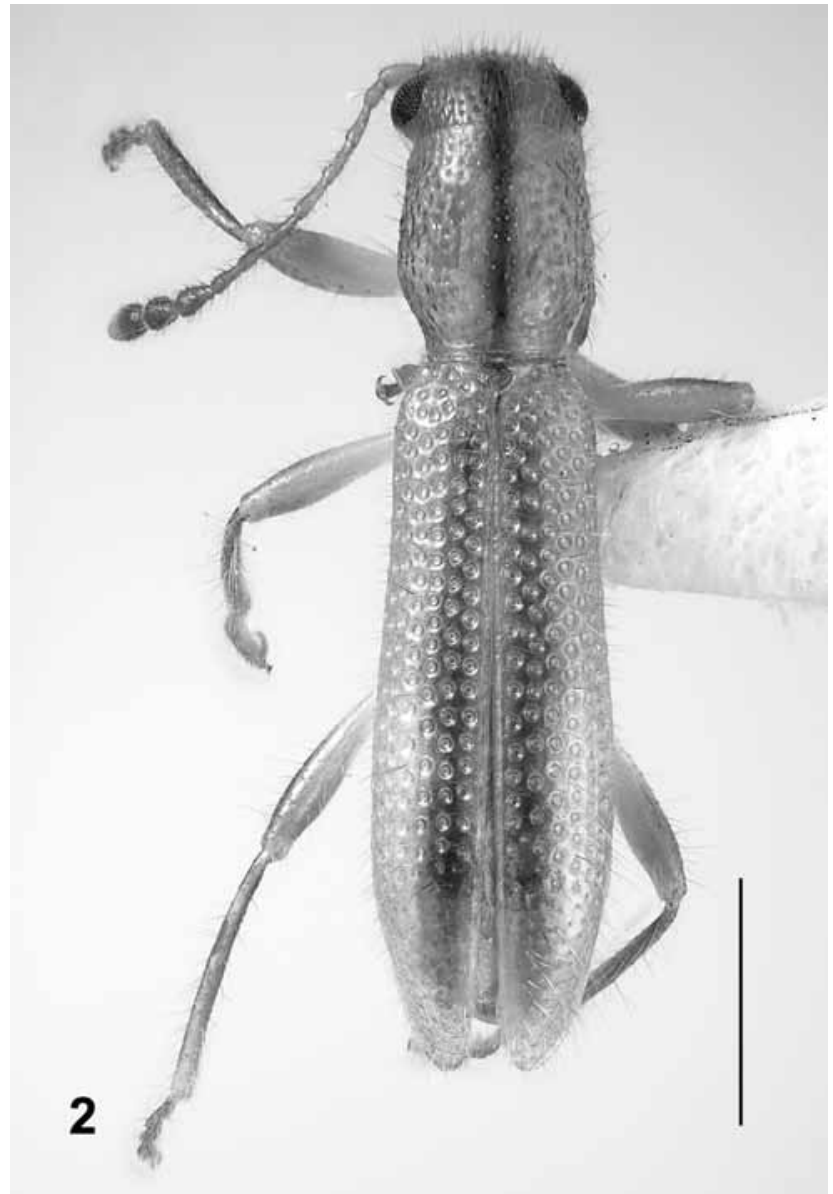

Figure 2. Tarsostenodes howensis n.sp. holotype, scale $=1 \mathrm{~mm}$.

with a short brown medial stripe on vertex; frontoclypeal suture entirely visible; vertex and frons impressed with circular foveolate punctation (punctations separated by their diameter or greater), clypeus smooth; ventral surface of head smooth, gular sutures long, strongly convergent; eyes reasonably small, laterally convex, deeply emarginate in front (kidney-shaped when viewed laterally), separated by 3.75 eye-widths, facets small but not particularly fine, several interfacetal setae present; terminal palpomeres securiform, distal margins of terminal maxillary palpomeres about as long as inner margins, distal margins of terminal labial palpomeres slightly longer than inside margins; antennae long, reaching beyond pronotal base, 11-segmented, A-3-8 slender filiform, A9-11 forming a gradual club, A9 elongate, A10 sub-cupuliform, A11 sub-ovate. Prothorax slightly elongate (length: width $=$ c. 1.2:1), about as wide as head and base of elytra; sides divergent in basal third, apical two-thirds weakly convergent (as viewed from above); pronotal disc with a brown medial stripe, widely distributed with foveolate punctation (similar to those on head); lateral carina virtually absent, vaguely present at extreme base; prosternum smooth, obscurely darkened; procoxal cavities closed, prosternal process posteriorly expanded. Elytra elongate (length:width = c. 2.5:1), sub-parallel, widest near apical third, apices reasonably acute; post basal region flat; each elytron with a longitudinal marking near the suture along most its length; 


\section{Key to Cleridae of Lord Howe Island}

1 Fourth tarsomere conspicuous, not hidden within lobes of the third 2

Fourth tarsomere small, cylindrical, hidden within lobes of the third 3

$2 \quad$ Large ( $>10 \mathrm{~mm}$ ) brown flightless species Cormodes darwini Pascoe

Small $(<10 \mathrm{~mm})$ dark metallic green species Lemidia subaenea Gorham

3 Prothorax with distinct lateral carina 4 Prothorax without distinct lateral carina Tarsostenodes howensis n.sp.

4 Elytra orange with a broad dark postbasal band Thriocerodes bipartitus (Pic) Elytra black with pale X-shaped markings Thriocerodes decussates n.sp.

disc regularly impressed with conspicuous circular foveolate punctation arranged in 10 rows, rows 1-8 (from suture) orderly, rows 9-10 disorderly; punctation suddenly absent before apex; epipleura converging near apical third. Hind wing functional, apical field one-quarter of total wing length; anal- and medial-field venation extremely faint, wedge cell apparently open. Pterothoracic sterna deeply impressed with circular foveolate punctation. Abdomen comprised of six visible sternites. Legs long, slender; all fourth tarsomeres reduced in length, cylindrical; tibial spur formula 1-2-1; tarsal pulvillar formula 3-3-3 (basal metatarsal pulvillus very small); pretarsal claws simple, slightly acuminate basally.

Etymology. The specific epithet illustrates the fact that T. howensis n.sp. is the only member of Tarsostenodes Blackburn known from Lord Howe Island, where it is presumably endemic.

Biology. Collected from $30 \mathrm{~m}$ to $280 \mathrm{~m}$ above sea level by beating Pandanus trees, Howea palms and other, unidentified, vegetation.

Remarks. The closure of the procoxal cavities, highly reduced lateral prothoracic carina, general form of the pronotum, characters of the eye (i.e. separation, emargination, size of facets), number of tibial spurs and tarsal pulvilli, suggest that this species is congeneric with members of Tarsostenodes (Tarsosteninae), a genus hitherto known only from eastern mainland Australia. Of the mainland species, $T$. howensis n.sp. appears to be most closely related to T. leucogramma Elston due to similarities in antennal length and type of punctation on the head and pronotum; $T$. luecogramma is also the only mainland species with which a "pale" variety is known. The new species is the only member of the genus lacking white callositous deposits on the elytra.
ACKNOWLEDGMENTS. Chris Reid (AMS) alerted me to the collection of Lord Howe Cleridae and Dave Britton (AMS) facilitated the loan of specimens. Tom Weir (ANIC) provided details for specimens held in the ANIC, Canberra. Max Barclay (BMNH), Thierry Deuve (MNHN), Peter Lilywhite (MVMA), Geoff Monteith (QM), and Jan Forrest (SAM) facilitated visits to collections in their care. Shaun Winterton (Queensland Primary Industries \& Fisheries) provided helpful comments on the manuscript.

\section{References}

DECC [Department of Environment and Climate Change (NSW)], 2007. Lord Howe Island Biodiversity Management Plan Appendices. Department of Environment and Climate Change (NSW), Sydney.

Ekis, G., 1977. Classification, Phylogeny, and Zoogeography of the Genus Perilypus (Coleoptera: Cleridae). Smithsonian Contributions to Zoology 227: 1-138.

Environment Australia, 2002. Lord Howe Island Marine Park (Commonwealth Waters) Management Plan. Environment Australia, Canberra.

Gerstmeier, R., 2000. Aktueller Stand der Buntkäfer-Forschung (Coleoptera, Cleridae, Thanerocleridae). Entomologica Basiliensia 22: 169-178.

Hardy, R.J., 1982. The biology and behaviour of currant borer moth, Synanthedon tipuliformis (Clerck) (Lepidoptera: Aegeriidae) in Tasmania. Journal of the Australian Entomological Society 21(2): 103-109.

http://dx.doi.org/10.1111/j.1440-6055.1982.tb01773.x

Lawrence, J.F., \& E.B. Britton, 1994. Australian Beetles. Melbourne University Press, Carlton, $192 \mathrm{pp}$.

New, T.R., 1978. Notes on the biology of Lemidia subaenea (Coleoptera: Cleridae) on Acacia in Victoria. Australian Entomological Magazine 5: 21-22.

Manuscript submitted 11 March 2009, accepted 9 July 2009. 